\title{
Actions, Attitudes, and the Obligation to Obey the Law
}

\author{
Noam Gur
}

If you put it to a contemporary legal or political theorist that 'there is no moral obligation to obey the law' it is highly unlikely they would be taken aback or raise an eyebrow. For such a denial is not only a mainstream position in modern scholarly discourse about the obligation to obey the law, but possibly even the currently dominant one. ${ }^{1}$ For students who make their first foray into the literature on this topic, however, this fact often comes as a surprise. ${ }^{2}$ They are surprised because the above, highly influential scholarly view appears to fly in the face of a basic idea they have absorbed from an early stage of their upbringing: the idea that law-abidingness is an integral part of good citizenship - that being a good citizen, as we all ought to be, implies inter alia being a law-abiding citizen. How are we to explain the apparent tension between this common pre-theoretical conception and the strong current of scepticism among scholars? If the arguments of sceptical scholars seem cogent, should we conclude that the socially prevalent attitude towards law, an attitude that emerged through a millennia-long civilisation process across a variety of

\footnotetext{
${ }^{1}$ See, e.g., Robert P. Wolff, In Defense of Anarchism (New York: Harper \& Row, 1970); M. B. E. Smith, 'Is there a prima facie obligation to obey the law?' Yale Law Journal, 82 (1973), 950-76; A. D. Woozley, Law and Obedience (London: Duckworth, 1979); Joseph Raz, The Authority of Law (Oxford: Clarendon Press, 1979), pp. 23349; A. John Simmons, Moral Principles and Political Obligations (Princeton, NJ: Princeton University Press, 1979); Carole Pateman, The Problem of Political Obligation (New York: Wiley, 1979); Rolf Sartorius, 'Political authority and political obligation', Virginia Law Review, 67 (1981), 3-17; David Lyons, 'Need, necessity, and political obligation', Virginia Law Review, 67 (1981), 63-77; Joseph Raz, 'The obligation to obey: revision and tradition', Notre Dame Journal of Law, Ethics \& Public Policy, 1 (1984), 139-55; Kent Greenawalt, Conflicts of Law and Morality (Oxford: Oxford University Press, 1987); Leslie Green, The Authority of the State (Oxford: Clarendon Press, 1988).

2 This anecdotal observation corresponds with the results of empirical studies about common attitudes of ordinary citizens (see, e.g., Tom R. Tyler, Why People Obey the Law (New Haven, CT: Yale University Press, 1990), p. 45)-attitudes whose existence is acknowledged by several of the above cited writers (see, e.g., Raz, The Authority of Law, p. 235; Simmons, Moral Principles and Political Obligations, p. 3; Smith, 'Is there a prima facie obligation to obey the law?', p. 975. See contra: Leslie Green, 'Who believes in political obligation?', For and Against the State, ed. J. Narveson and J. T. Sanders (Lanham, MD: Rowman \& Littlefield, 1996), pp. 10-14).
} 
cultures, is the product of a sheer error or a mere superstition that ought to be rooted out?

In this article I will reject this possibility and will try to make some headway towards an alternative explanation. I say 'some headway' because a full explanation of the relation between the scholarly and the popular views would extend beyond the confines of this article and will not be attempted here. What I will do, however, is to examine each of them and argue that (i) at least under certain ethical presuppositions, there is a strong case for denying the obligation to obey the law; but (ii) even if there is no obligation to obey the law, the common attitude of law's subjects, that is, their law-abiding disposition, reflects not a regrettable error but a desirable attitude which they have good reasons to retain.

I will pursue this inquiry in two stages. First, in Sections I and II the question of the obligation to obey the law will be analysed through an evaluative prism that focuses on the moral implications of our actions (of obedience or disobedience), rather than the moral implications of our attitudes towards law. This analysis will point to the conclusion that although there is an obligation to obey some laws in some situations, and although the scope of that obligation is wider than it may appear at first glance, it nevertheless falls short of a general obligation to obey the law. In Section III, the focus of my analysis will shift from the moral implications of our actions to the moral implications of our attitudes. I will argue that, even if it is true that there is no general moral obligation to act in compliance with law, it is nonetheless a morally valuable thing that (as subjects of a reasonably just legal system) we have the attitude of law-abiding citizens, the attitude of being disposed to comply with law.

A number of preliminary clarifications are called for. Firstly, throughout this article I will be using the terms 'obligation' and 'duty' interchangeably, rather than strictly adhering to the distinction drawn by writers such as Hart and Rawls according to whom obligations, unlike duties, arise as a result of voluntary acts. ${ }^{3}$ Secondly, when using the phrase 'an obligation to obey the law', I should be taken to mean (i) a moral and not merely legal obligation (if there can be such a thing as a genuine obligation that is legal but not moral); (ii) a prima facie rather than absolute obligation; ${ }^{4}$ (iii) an obligation to obey the law qua law as opposed to an obligation arising from the specific content adopted by some laws; and (iv) a general obligation to obey the law rather than an obligation whose scope is confined to only some subset of laws or situations to which they apply.

\footnotetext{
${ }^{3}$ See H. L. A. Hart, 'Legal and moral obligation', Essays in Moral Philosophy, ed. A. I. Melden (Seattle: University of Washington Press, 1958), pp. 100-5; H. L. A. Hart, 'Are there any natural rights?' Philosophical Review, 64 (1955), 175-91 at fn. 7; Richard B. Brandt, 'The concepts of obligation and duty', Mind, 73 (1965), 374-93; John Rawls, A Theory of Justice, rev. ed. (Cambridge, MA: Harvard University Press, 1999), pp. 93-101; Simmons, Moral Principles and Political Obligations, pp. 11-16. Cf. Tony Honoré, 'Must we obey? Necessity as a ground of obligation', Virginia Law Review, 67 (1981), 39-61 at pp. 47-8.

${ }^{4}$ On prima facie duties see W. D. Ross, The Right and the Good (Oxford: Oxford University Press, 1930), ch. II.
} 
Thirdly, I should note that no attempt will be made here to provide a comprehensive analysis of all possible arguments for the obligation to obey the law. Such analyses are offered in the existing literature and their replication is both impossible and unnecessary in an article whose primary objective is not to conclusively resolve the question of whether there is an obligation to obey the law, but rather to show the pertinence and significance of a law-abiding attitude. Rather than discussing the full range of arguments for the obligation to obey the law, then, I will focus on two types of argument that I consider to be the most relevant and fruitful for the purpose of this inquiry: namely, arguments based on necessity considerations and on fairness considerations. There is, however, a third type of argument-based on the notion of consent-which is too important to be set aside without at least briefly indicating why I consider it to be unpromising: the main reason, highlighted by several writers, is that very few people have actually consented to come under a general obligation to obey the law. ' 'The paucity of express consentors', as A. John Simmons writes, 'is painfully apparent', ${ }^{6}$ whereas tacit consent to an obligation to obey the law cannot be widely inferred without 'stretching the notion of consent far beyond the breaking point', ${ }^{7}$ for example, by inferring it from the act of voting in democratic elections, which is less than a clear and unequivocal sign of a deliberate undertaking of such an obligation; 8 or from the fact of residence, which, given the practical difficulties involved in emigrating, let alone the practical impossibility of finding a territory with no sovereign at all, effectively lacks the degree of free choice and available alternatives requisite for the binding force of consent. ${ }^{9}$

A fourth and final preliminary comment concerns a working premise I will adopt for purposes of this analysis: I will assume that one of the necessary conditions for there to be a moral obligation to perform some action ('A') is that either $A$ itself or its consequences satisfy or serve some moral value (or that failing to perform $A$ would frustrate or disserve something morally valuable).

\footnotetext{
5 See, e.g., David Hume, 'Of the original contract', in Hume, Political Essays, ed. K. Haakonssen (Cambridge: Cambridge University Press, 1994), pp. 186-201; Smith, 'Is there a prima facie obligation to obey the law?', pp. 960-4; Simmons, Moral Principles and Political Obligations, pp. 57-100; cf. Joseph Raz, The Morality of Freedom (Oxford: Clarendon Press, 1986), pp. 80-94. For a recent defence of consent-based arguments, see David M. Estlund, Democratic Authority (Princeton, NJ: Princeton University Press, 2008), pp. 117-35.

${ }^{6}$ Simmons, Moral Principles and Political Obligations, p. 79.

${ }^{7}$ Ibid.

${ }^{8}$ See A. John Simmons, On the Edge of Anarchy (Princeton, NJ: Princeton University Press, 1993), pp. $218-24$.

${ }^{9}$ See, e.g., Hume, 'Of the original contract', p. 193; Ronald M. Dworkin, Law's Empire (London: Fontana, 1986), pp. 192-3. Another type of theory which I will not be able to discuss here is associative obligation theory. For statements of the theory see, e.g., Dworkin, ibid., pp. 195-215; John Horton, Political Obligation, 2 nd ed. (Basingstoke: Macmillan, 2010), pp. 135-91. See contra: A. John Simmons, Justification and Legitimacy (Cambridge: Cambridge University Press, 2001), pp. 65-92. For a recent reformulation of associative obligation theory in 'quasi-voluntarist' terms, see Massimo Renzo, 'Associative responsibilities and political obligation', Philosophical Quarterly, 62 (2012), 106-27.
} 
As the word some suggests, the condition will not be associated with any particular value-it will not, for example, be exclusively linked with utility or welfare-but rather will be understood broadly as including anything that can tenably be regarded as a value. Thus, for example, if $A$ is valuable in terms of its fairness, that is, if failing to perform $A$ would be unfair, then $A$ meets the above eligibility condition and we may at least consider whether it is morally obligatory. To be sure, not all philosophers would accept the eligibility condition stated above; not all would be content with the focus it places on the moral implications of our actions (rather than, say, the maxims by which we are guided). ${ }^{10}$ Nevertheless, it is requisite for purposes of this inquiry to assume this condition, because it underpins much of the contemporary scepticism about the obligation to obey the law, ${ }^{11}$ and because a primary aim of this article is to show that even from that sceptical viewpoint the value of a law-abiding attitude should be acknowledged.

So much for preliminaries. I now turn to an examination of some arguments for the obligation to obey the law.

\section{NECESSITY}

The first argument I will consider is based upon the notion of necessity. This argument finds one of its clearest and most prominent expressions in David Hume's essay 'Of the Original Contract', ${ }^{12}$ in which he denies that the civic duty of obedience to government is grounded in a social contract or an act of consent, and derives it instead from 'the interest and necessities of society'. ${ }^{13}$ Hume encapsulates the gist of this argument when he states:

\footnotetext{
${ }^{10}$ See, e.g., Immanuel Kant, Groundwork of the Metaphysics of Morals, 4:421, Critique of Practical Reason, 5:72, and The Metaphysics of Morals, 6:389.

${ }^{11}$ See, e.g., Raz, The Authority of Law, pp. 237-42, Raz, 'The obligation to obey: revision and tradition', 145-55 (who, in denying the obligation to obey the law, points out situations where 'conforming with the law will serve no useful purpose' and where failures to conform will amount to 'innocuous acts which neither harm any one nor impede the provision of any public good'); Smith, 'Is there a prima facie obligation to obey the law?', pp. 956-60, 969-73 (who invokes the fact that 'because laws must necessarily be designed to cover large numbers of cases, obedience to the law often benefits no one ... [and that] virtually every legal system contains a number of pointless . . . laws, obedience to which . . . benefits no one'); Donald H. Regan, 'Law's halo', Social Philosophy \& Policy, 4 (1986), 15-30 at pp. 15-19 (e.g., '[t] he fact I am pointing to when I say there is no obligation to obey the law is . .. [that] there are some cases where a particular act is illegal but where there is no moral reason at all to avoid that act'); Leslie Green, 'Legal obligation and authority', Stanford Encyclopedia of Philosophy, ed. E. N. Zalta <http://plato.stanford.edu/entries/legal-obligation/> (whose denial of an obligation to obey relies, inter alia, on facts such as this: 'a legal system can, and does, tolerate a certain amount of harmless disobedience ...').

${ }^{12}$ Note 5 above. See also G. E. M. Anscombe, 'On the source of the authority of the state', Authority, ed. J. Raz (New York: New York University Press, 1990), pp. 142-73, and Honoré, 'Must we obey? Necessity as a ground of obligation'. See contra: Smith, 'Is there a prima facie obligation to obey the law?', pp. 964-5; Leslie Green, 'Law and obligations', The Oxford Handbook of Jurisprudence and Philosophy of Law, ed. J. L. Coleman and S. Shapiro (Oxford: Oxford University Press, 2002), pp. 535-9.

13 Hume, 'Of the original contract', p. 200. See also ibid., p. 197.
} 
A small degree of experience and observation suffices to teach us, that society cannot possibly be maintained without the authority of magistrates, and that this authority must soon fall into contempt, where exact obedience is not payed [sic] to it. The observation of these general and obvious interests is the source of all allegiance, and of that moral obligation, which we attribute to it. $^{14}$

It is essential, however, that we further unpack the argument in order to adequately scrutinise it. There appear to be three main premises that the argument contains or presupposes. First, it appears to be predicated upon the following assumption:

[N1] People have a duty to uphold, or at least not to undermine, institutions or schemes that are necessary for securing (at least) tolerable living conditions (inevitably, institutions or schemes that enable life in a society). ${ }^{15}$

The first thing to note is that N1, like the rest of the argument from necessity, expresses a nonvoluntarist principle. It belongs to a class of requirements that are thought to apply to us irrespective of whether we have willed or consented to them. ${ }^{16}$ Other notable members of this class include, for example, our duty to refrain from injuring others, or to come to the aid of another in serious jeopardy or need (provided we can do so without excessive risk or loss). Those who believe that we are subject to these duties do not usually assume this to be contingent on whether or not we have voluntarily committed ourselves to act in the above ways. ${ }^{17}$

So too, according to the argument from necessity, our duty not to undermine arrangements which are necessary for securing tolerable living conditions in society is a moral precept incumbent upon us regardless of our will or consent.

The second premise of the argument from necessity is this:

[N2] Governance through law is necessary for securing certain goods without which an acceptable life for members of society would not be possible. ${ }^{18}$

Consider, for example, the infrastructure that a society requires for its operation ${ }^{19}$ or the organised forces needed for national defence against attacks by foreign enemies. These are essential goods whose provision necessitates forms of social cooperation that are not likely to be achieved in the absence of government and its legal means of guiding conduct. In like manner, governments are necessary for securing the degree of social order, stability, and interpersonal forbearance that is requisite for an acceptable life; in the absence of laws, judges, and policemen, 'encroachments of the strong upon the weak, of the violent upon the just and equitable'20 would proliferate and pervade our life-society would thus

\footnotetext{
${ }^{14}$ Ibid., p. 196. See also Anscombe, 'On the source of the authority of the state', pp. 147, 151, 172.

${ }^{15}$ For a similar proposition, see Anscombe, 'On the source of the authority of the state', pp. 159-60.

${ }^{16}$ See Rawls' discussion of natural duties in A Theory of Justice, $§ 19$.

17 Ibid.

${ }^{18}$ Hume, 'Of the original contract', p. 187. See also ibid., pp. 196-7.

${ }^{19}$ Such as facilities and secured pathways which are necessary for steady supply of food and water.

${ }^{20}$ Hume, 'Of the original contract', p. 197.
} 
lapse into a state of nature in which our physical integrity and basic means of living would be subject to constant transgressions by other members of society. ${ }^{21}$

An important objection that may be raised at this point insists that although life in the state of nature is likely to be nasty, brutish, and short, it should not be assumed that life in any lawgoverned society would be better. As history bears witness, there can be regimes that are so extremely iniquitous that one might doubt whether life under their rule would be preferable to life in a lawless society. In responding to this objection I will make no attempt to determine which of those two evils, the horrors of widespread anarchy or of extremely iniquitous regimes, might be the greater (a question that might not lend itself to a definitive answer). Instead, I shall defuse the objection by introducing into the analysis the following qualification: henceforth the argument from necessity, like all other arguments that will figure in this article, should be read as limited to political and legal systems that pass the minimum threshold of being morally tolerable ${ }^{22}$-systems that we can refer to as reasonably just. ${ }^{23}$

We may now turn to the third premise of the argument from necessity:

[N3] If we break the law we would thereby undermine the government's efforts and ability to fulfil the above essential functions. ${ }^{24}$

It should be made clear that premise N3 expresses a concern not only with the direct and immediate consequences of our disobedient actions, but also with their likely influence on the behaviour of other actors (hereinafter the argument from example): those who witness or hear about our disobedient actions would often be stimulated this way into breaking the law themselves. And if lawbreaking behaviour thus reaches a certain degree of pervasiveness in society, even those who were initially disposed to comply with law would see little or no point in doing so.

Now, if premises N1, N2, and N3 were all correct it would follow that we have an obligation to obey the law. But they are not. At least one of these premises, N3, mistakes or at any rate grossly exaggerates the true facts. As Joseph Raz critically remarked, 'it is a melodramatic exaggeration to suppose that every breach of law endangers, by however small a degree, the survival of the government, or of law and order'. ${ }^{25}$ For, first, the powerful coercive apparatus

\footnotetext{
${ }^{21}$ Thomas Hobbes, Leviathan, ed. R. Tuck (Cambridge: Cambridge University Press, 1991), pt. I, ch. XIII.

22 This is not to say that the obligation under discussion entirely ceases to be content-independent (as stipulated earlier), but rather that its content-independence is merely relative, rather than absolute: it is an obligation that applies to a wide, but not unlimited, range of possible 'contents' that lawmakers may adopt.

${ }^{23}$ I will be using the general term 'reasonably just' without attempting to further specify its boundaries by reference to examples or more concrete criteria. People may disagree on whether this or that system is reasonably just, but this should not affect the correctness of my arguments. It only means that the arguments leave room for disagreement on the instances to which they apply.

${ }^{24}$ Hume, 'Of the original contract', p. 196.

${ }^{25} \mathrm{Raz}$, The Morality of Freedom, p. 102.
} 
governments usually have at their disposal means that they can effectively handle a fairly significant amount of disobedience and maintain their grip on the population in the face of some recalcitrant behaviour. ${ }^{26}$ Second, although certain public acts of civil disobedience that express revolt against the government, or some law contraventions by highly visible legal officials, may have a significant impact on socially accepted attitudes towards the law, this is hardly the case with most types of law violation by a private citizen. Given the typically large size of modern political societies, an ordinary individual may plausibly assume that an act of disobedience on her part would have no, or no more than negligible, effect on the general habit of obedience in society.

True, if everyone relied on this assumption and regularly disobeyed the law the resulting threat to the law's efficacy would be far from negligible. This last statement, however, is a hypothetical statement ('If everyone...'); it does not purport to be a description of existing facts. Nor does it purport to describe an outcome that would actually follow from an act of law violation in ordinary conditions. As such, that statement is not relevant to our analysis in this section, which focuses purely on necessity considerations (though it will become relevant in the following section, when fairness arguments will be integrated into the analysis). From the perspective of our current assessment, what matters is the actual impact our actions are likely to have on necessary social arrangements-that is, their likely impact in light of true facts. ${ }^{27}$ From this perspective, then, the material consideration is that in fact it is not the case that all or most people regularly disobey the law nor is it realistic to suppose that one's act of disobedience would change that situation.

A third and final point that serves to debunk N3 is that there are situations where violating a law would be entirely harmless as well as impervious to the argument from example. Consider the familiar example of a driver who comes upon a red traffic light where it is clear that there are no other cars or pedestrians in the vicinity ${ }^{28}$ - say, on a lonely road in the desert when the visibility is very

\footnotetext{
${ }^{26}$ Smith, 'Is there a prima facie obligation to obey the law?', p. 958; Green, 'Law and obligations', p. 537.

${ }^{27}$ This premise resonates with consequentialism in its paradigmatic form: namely, act-consequentialism. It does not correspond with a full-blooded version of rule-consequentialism (what Brad Hooker calls full ruleconsequentialism: see his entry 'Rule consequentialism', in Stanford Encyclopedia of Philosophy, ed. E. N. Zalta <http://plato.stanford.edu/entries/consequentialism- rule>), which is a theory that not only uses a consequentialist criterion to select rules that should guide our practical deliberation, but also contends that such rules determine the moral quality of an action within their ambit (regardless of the action's consequences). However, full ruleconsequentialism has been impliedly set aside here when I postulated the working premise that an action cannot be morally obligatory if it serves no moral value (text between notes 9 and 11). Incidentally, I should note that, pace Hooker (Ideal Code, Real World (Oxford: Oxford University Press, 2002), pp. 99-111), I have doubts as to whether full rule-consequentialism is really consequentialism, though this is a question that cannot be taken up here.

${ }^{28}$ See, e.g., Raz, The Authority of Law, p. 16; Smith, 'Is there a prima facie obligation to obey the law?', p. 971; Regan, 'Law's halo', pp. 18-19; Heidi M. Hurd, 'Challenging authority', Yale Law Journal, 100 (1991), 1611-77 at p. 1614; William A. Edmundson, Three Anarchical Fallacies (Cambridge: Cambridge University Press, 1998), pp. 12-34.
} 
good-and, thus, running the red light would not cause any physical harm or be seen by others and stimulate them into disobedient behaviour. ${ }^{29}$ Even if we assume that such situationswhere it is completely clear that violating the law would have no negative effects-are rather infrequent, they nevertheless exist and thus serve as valid, and very clear, counterexamples to premise N3.

The foregoing observations suggest that, far from establishing a general obligation to obey the law, the argument from necessity grounds, at best, an obligation whose scope is confined to certain individuals, laws, or situations. That is, it grounds an obligation that applies only when and insofar as an act of non-compliance would have an appreciable destabilising effect on the government's effective authority. In the following section, I will consider whether a fortified version of this argument, which integrates, alongside necessity considerations, notions of fairness, can succeed where the original argument has failed.

\section{FAIRNESS INTEGRATED}

Like the previously examined argument, the variant to which I now turn (which can be called the integrated argument) relies on the assumption that government is necessary for the attainment and protection of essential goods in social life. However, it does not suppose that government's ability to provide and safeguard these goods can actually be undermined by an ordinary law violation of a private citizen. Instead, it invokes fairness considerations in order to close the gap between, on the one hand, the necessity of avoiding an actual breakdown of law and order and, on the other hand, a general obligation to obey. More specifically, this argument contends that an agent who contemplates breaking a law should, instead of relying on premise N3 above, reason in the following way:

[F1] Although a law violation on my part would have no more than a negligible effect on the law's efficacy, if everyone disobeyed the law the cumulative effect would be far from negligible and the legal system's ability to fulfil its necessary functions would be undermined.

[F2] It is therefore necessary that people in general obey the law and this is what I expect from them.

[F3] As I expect others to obey the law and I gain essential benefits from the fact that they do, it is only fair that I do the same, instead of acting as a free rider. ${ }^{30}$

Now, although this line of reasoning improves upon the pure necessity argument examined above and strengthens the grounds for an obligation to obey the law, it is nonetheless guilty of over-generalising. I will suggest that a duly qualified version of this argument still falls short of grounding a general obligation to obey the law.

${ }^{29}$ Let us also assume that disobedience on this particular occasion would not change his general attitude towards law. I will discuss the attitudinal dimension in Section III.

${ }^{30} \mathrm{Cf}$. H. L. A. Hart, 'Are there any natural rights?' pp. 185-6; John Rawls, 'Legal obligation and the duty of fair play', Law and Philosophy, ed. S. Hook (New York: New York University Press, 1964), pp. 3-18. 
Before I turn to this issue, however, another possible objection against the integrated argument should be mentioned and rejected. The objection I have in mind contends that a fairness-based obligation to comply with a cooperative scheme arises only when the benefits of the scheme have been voluntarily accepted. ${ }^{31}$ However, the objection continues, receipt of public goods such as the benefits of national defence or social order cannot be regarded as voluntary for the simple reason that, when these goods are supplied in a given country, all residents inevitably receive them. These goods are unavoidable in the sense that, so long as one resides in the relevant country, one has no opportunity not to receive them; and even if one could avoid them by emigrating-which is doubtfully the case because in the real world there seems to be no territory that is quite as anarchic as the hypothetical state of nature-given the difficulty involved in relocating one's life to a foreign country, declining to do so can hardly be regarded as the product of free choice. According to the objection, therefore, receipt of such benefits is not to be treated as a voluntary act capable of giving rise to a fairness-based obligation.

This objection appears cogent when levelled against the traditional and basic type of fair-play argument. ${ }^{32}$ It is not a good objection, however, against the argument we are now discussing, which is an argument that combines fairness considerations with necessity considerations. Even if benefiting from public goods such as social order, protection against interpersonal violence, or national defence does not amount to voluntarily choosing them, the fact that such goods are indispensable for an acceptable life suggests that virtually all people would opt for them if given a free choice and would pursue them if that was necessary for their receipt. ${ }^{33}$ They would certainly do so if they faced the dire consequences liable to occur when those vital goods are absent, for example, in conditions that exposed them to imminent danger of death, bodily harm, or sexual assault. If there exist individuals who would even in such conditions genuinely reject those goods, these are likely to be individuals bereft of minimum rationality and sound mind, who therefore also lack the moral competence needed in order to be the bearers of, not just an obligation to obey the law, but any obligation. The position of such individuals, however, is of little or no interest in the context of our inquiry. ${ }^{34}$ These abnormalities aside,

${ }^{31}$ See, e.g., Rawls, A Theory of Justice, pp. 96-101; Robert Nozick, Anarchy, State, and Utopia (Oxford: Blackwell Publishing, 1974), pp. 93-5; Simmons, Moral Principles and Political Obligations, pp. 118-42; Dworkin, Law's Empire, pp. 192-3.

${ }^{32}$ Hart, 'Are there any natural rights?', pp. 185-6; Rawls, 'Legal obligation and the duty of fair play', pp. 3-18.

33 George Klosko, 'Multiple principles of political obligation', Political Theory, 32 (2004), 801-24 at pp. 805-6; George Klosko, The Principle of Fairness and Political Obligation (Lanham, MD: Rowman \& Littlefield, 1992), pp. 39-57.

34 Contrast this with Simmons' comments in Justification and Legitimacy, pp. 32-3 and in Christopher $\mathrm{H}$. Wellman and A. John Simmons, Is There a Duty to Obey the Law? (Cambridge: Cambridge University Press, 2005), pp. 133-4, 140-1. 
the fact that the vital goods in question are clearly such that one would opt for them if given a free choice, in conjunction with the fact that one actually benefits from them, ${ }^{35}$ seems to me sufficient to fill the, so to speak, normative gap left by the absence of actual voluntary acceptance. ${ }^{36}$ To get a clearer view of this point, imagine an individual ('John') who enjoys a basic public good (' $X$ '), which is absolutely essential for people's (including his own) physical security and health, but who declines to share the collective burdens through which $X$ is made available. Again, $X$ may consist of goods such as national defence, crime prevention, the maintenance of public order, or infrastructural services essential for public health (e.g., a municipal sewer system and refuse collection and disposal), whose provision, let us suppose, is made possible through a specific tax designated for that purpose or, in the former examples, through collective participation in a military or civil service.

Now suppose that one of John's fellows ('Tim') gives vent to his disapproval of John's free riding and puts it to him that his behaviour is unfair. Given that $X$ is a vital and indispensable good, it is hard to imagine what John could say in reply, unless he could point out some morally relevant difference between him and his fellow citizens, perhaps a genuine conscientious objection or a religious belief that prevents him from taking part in the relevant activity. ${ }^{37}$ Suppose that he is unable to point out any such personal attribute that sets him apart from his fellows and that his response to Tim's condemnation is this: 'how can you say that my failure to uphold $X$ is unfair when no one has ever asked me whether I actually want the benefits of $X$ and I have never requested it?' Tim replies: 'but $X$ is necessary for your own physical security and health, so not only do you benefit from it, but clearly you would also opt for it if given the choice. Indeed, if you were faced with the adversities that $X$ prevents, you would be yearning for it.' If Tim's last statement is correct (as it is likely to be, given the nature of $X$ ) then John is morally barred from using the argument that he has never voluntarily chosen the goods in question; the dissonance between that argument and his true preferences would amount to insincerityhis claim would not be bona fide. If, on the other hand, Tim's statement is incorrect because John is in fact entirely indifferent to the physical integrity of others and, oddly enough,

\footnotetext{
35 It will also be recalled that the goods under consideration are public goods dependent on a cooperative scheme.

${ }^{36} \mathrm{My}$ stance in this regard is largely consistent with that of Klosko, who labels such goods 'presumptively beneficial goods' (note 33 above). See contra: Simmons, Justification and Legitimacy, pp. 31-6. Simmons' counterexamples are, I think, unpersuasive, because they involve goods which are not 'presumptively beneficial' (ibid., p. 33), or which the relevant agent does not actually consume (ibid., p. 34), or which he could effectively secure by himself, independently of the cooperative scheme, but the scheme prevents him from doing so (ibid., p. 36).

37 Klosko, The Principle of Fairness and Political Obligation, pp. 42, 52. As for conscientious objection, Klosko plausibly suggests that even such exempting circumstances do not mean that no moral obligation has arisen in the first place, but rather only that the obligation is overridden by a conflicting moral claim (ibid., p. 52).
} 
himself, or perhaps even perversely desires to be subject to violence and suffer bodily harm, then, once more, John seems to fall outside the range of minimally rational and morally competent agents capable of bearing any kind of obligation-in which case his position is hardly interesting from the perspective of an inquiry about the obligation to obey the law. ${ }^{38}$

So far we have observed that an argument which integrates necessity and fairness considerations has two main advantages over arguments that draw on necessity or fairness alone: first, unlike a pure necessity argument, the integrated argument holds good beyond the confines of situations in which a disobedient act would actually destabilise the law's effective authority; and, second, unlike the traditional fair-play argument, the integrated argument holds good irrespective of whether the relevant actor has voluntarily opted for the goods in question. It appears therefore that, while considerations of necessity or fairness alone can only ground an obligation of a relatively narrow scope, their combination yields an obligation whose scope is significantly wider than the sum of its parts. ${ }^{39}$

Despite all this, however, even the integrated argument is liable to the charge of overgeneralising. The reason is that, as it stands, the integrated argument is insufficiently sensitive to the question of whether a given act of disobedience-performed by one or any number of people-would have any adverse effect on the relevant cooperative scheme or its participants. If one benefits from a cooperative scheme, it may be unfair to other participants that one acts in a way that deprives them of similar benefits or causes some harm to the scheme, or that one performs an action which, if performed by a sufficiently large number of other people, would cumulatively have such negative effects. But when the action would have no negative effect whatsoever, whether performed by one or any larger number of participants, it is hard to see why it should be regarded as unfair to anyone. ${ }^{40}$ Consider once more the example of the traffic light in the desert. ${ }^{41}$

In such circumstances it is clear that stopping at the red light would not benefit anyone and that failing to stop would cause neither physical injury nor spread of disobedience. Nor does it implicate a state of imbalance which favours one individual over the rest: for why should we not accept, as a qualification of F1-F3 above, that all people who find themselves in that special situation may violate the law? Given that running the red light in those circumstances would have no adverse effect whatsoever, even if all people who come upon a traffic light in those

\footnotetext{
${ }^{38}$ See note 34.

39 The integrated approach I have taken here shares certain features with Klosko, 'Multiple principles of political obligation', and Christopher Wellman, 'Toward a Liberal Theory of Political Obligation', Ethics, 111 (2001), 735-59 at pp. 740-54.

${ }^{40} \mathrm{Cf}$. Smith, 'Is there a prima facie obligation to obey the law?', pp. 954-8; Simmons, Moral Principles and Political Obligations, p. 106, fn. p. See also Edmundson, Three Anarchical Fallacies, p. 31.

${ }^{41}$ See text accompanying notes 28 and 29.
} 
circumstances declined to stop, society would not be worse off, not in the slightest. ${ }^{42}$ This means that an individual who performs this act does not, eo ipso, assume a liberty or gain an advantage that, as a rational actor, he would not be willing to extend to others-so his action should not be regarded as unfair. Thus, it appears that even the integrated argument falls short of establishing a general obligation to obey the law. ${ }^{43}$ At most, it grounds an obligation that applies in many but not all situations.

\section{A PROBLEM OF ATTITUDE}

I said above that there is nothing wrong with an act of law violation done in situations such as the lonely traffic light case. I now want to suggest that, correct as it may be, this statement omits an important issue. The merit of the act is not the only question worthy of consideration in the context of our inquiry. ${ }^{44}$ To see this it should first be brought to mind that a person's actions in different situations-including in the lonely traffic light case-do not occur entirely independently of each other, but rather share at least one common source: they are all his actions, and as such flow (at least partly) from his practical attitudes. A person's attitudes towards practically significant aspects of the world around him tend to influence the way he acts, ${ }^{45}$ and, more specifically pertinent to us, a person's attitude towards a normative practice such as law tends to influence the actions he performs when faced with legal requirements. ${ }^{46}$ This means that, when analysing situations such as the lonely traffic light case, we ought to assess not only the action performed-i.e., stopping at the red light or failing to do so-but

\footnotetext{
42 I set aside here possible counter-arguments that implicate the attitudinal aspect of our problem. I discuss the role and significance of relevant attitudes in Section III below.

${ }^{43}$ One might insist that the above action is morally wrong, not qua action of driving in certain circumstances, but rather qua action of law violation. This, however, would beg the question. Why should we regard an action of law violation as morally wrong? This cannot be meaningfully answered without reference to some other features of the action or its consequences (which is what I have tried to do in the last two sections) or, perhaps, the attitude or mode of reasoning from which it ensues (which is what I will do, or at least begin to do, in the following section).

${ }^{44}$ Nothing I will say here is intended to deny that actions are normatively significant or that we have moral duties to perform or avoid certain actions-including, in some cases, acts of compliance with law. Rather, my contention is that exclusive focus on actions leads to a crucially incomplete account of law's normative force.

${ }^{45}$ This is not to suggest that our attitudes and actions are always perfectly aligned. For one thing, there are other factors that may influence behaviour, e.g., external pressures, interests, or needs. For another, the degree of correlation may depend on variables such as the types of attitude and behaviour involved. But it is undeniable that some of our attitudes tend to affect some of our actions (e.g., ceteris paribus, parsimonious people are less likely than others to spend money, risk-averse people are less likely than others to engage in risky ventures, and lawabiding people are less likely than others to break the law). For an instructive discussion of the influence of attitudes on behaviour, and an overview of relevant empirical literature, see Icek Ajzen and Martin Fishbein, 'The influence of attitudes on behavior', The Handbook of Attitudes, ed. D. Albarracín, et al. (Mahwah, NJ: Erlbaum, 2005), pp. 173-221.

${ }^{46}$ See, e.g., Tyler, Why People Obey the Law, pp. 57-64.
} 
also the attitude towards law that such an action presupposes and the likely effect of that attitude on our actions in other situations.

Let us consider, then, the normative attitude from which disobedience in the lonely traffic light case may ensue. We need not detain ourselves for this purpose with the attitude of the 'bad $\operatorname{man}^{\prime 47}$ who, within law or elsewhere, cares nothing for the moral implications of his actions. That such an attitude is morally condemnable is most trivially true. Far more interesting for our purpose is the attitude of someone who is concerned to act morally but nonetheless decides not to stop at the lonely traffic light. Also suppose that the circumstances of his action are not such that they present him with any special reasons to run the red light, that is, reasons other than the mere fact that he would save time this way (it is not the case, for example, that by running the red light he would avoid being late for an important business meeting). He disobeys the law in this instance because he recognises that, although obeying it would cause no harm (apart from the trivial loss of a few seconds), it would also yield no benefit to anyone, and he takes this to be sufficient reason to disobey.

This means that he does not attach in his practical reasoning any normative significance to law qua law (otherwise he would have probably stopped at the red light in the above situation, where there are no, or only trifling, reasons not to). He does not regard the very fact that law requires an action as a reason for its performance. Instead, he regards law as entirely transparent to its underlying objectives and values, examining in each case whether and to what extent compliance with the applicable legal rule would serve desirable substantive goals which underlie the rule (e.g., the prevention of road accidents) and, possibly, whether non-compliance would set an example to other individuals which would have negative influence on their conduct. If he believes that no such reasons for compliance apply to the case at hand, as in the desert traffic light situation, he breaks the law. In other situations, where he thinks that some such reasons do apply, he would weigh them against the reasons he believes himself to have for non-compliance, and would act upon his assessment of the balance of reasons. In the discussion that follows I will sometimes use the phrase lawindifference as shorthand for the above mode of reasoning and attitude towards law.

One fairly obvious problem with the above-described method of practical reasoning is the excessive amount of time and mental labour it consumes, which makes it a highly inefficient procedure of decision-making for purposes of everyday activity. ${ }^{48}$ However, the primary defect in this method of reasoning and

${ }^{47}$ Oliver W. Holmes, 'The path of the law', Harvard Law Review, 10 (1897), 457-78 at p. 459.

48 This problem alone could be overcome by employing heuristics about when to obey or disobey. But the biases I will discuss here, and the motivational problems they implicate, show why mere heuristics would not do, and explain the need for the type of normative internalisation and attitude I will advocate here. 
in the attitude it implicates is not so much their procedural inefficiency as their high susceptibility to substantive error. The problem, in other words, is that those who reason in that way and have that attitude towards law are not likely to strictly confine their departures from law only to the circumstances of a traffic light in the desert as depicted above, but rather are likely to end up departing from law in other situations, including situations in which doing so is in fact sub-optimific and unfair. Why so? A brief reflection on the settings and conditions in which the above method of practical reasoning would be typically used should make this clear.

It should first be brought to mind that when making the above assessments as subjects of the law, we would not be operating in neutral 'laboratory conditions' free from temptations to break the law and optimally suited to facilitate rational decision-making. Rather, we would be making those assessments in our everyday settings of activity under the law-settings that frequently expose us to stimuli that pull the assessment in the direction of noncompliance, such as the immediate inconvenience involved in following the rule and the short-term personal gains often attainable by breaking it. In these conditions of decisionmaking our assessments of law-following values would tend to be partial, short-sighted, and influenced by other situational biases. ${ }^{49}$

Thus, for example, the perception and judgement of a driver who rushes to his destination or is eager to arrive home after a long day of work is not likely to be impervious to the biasing influence of such motivational forces. He may thus easily be led to underestimate the dangers involved in exceeding the speed limit, overtaking on a solid line, or running a red light at a seemingly empty junction, and the chance of him misjudging the situation is itself not something he is likely to readily and fully recognise when thus placed. This is so not only because people are often not very good at acknowledging their own limitations, incompetence, and ill judgement-an empirically proven tendency known to psychologists as the self-enhancement bias. ${ }^{50}$ It is also due to a myopic bias borne out in a series of experimental studies and labelled in behavioural science jargon

\footnotetext{
49 For a comprehensive discussion of these biases see my 'Normative weighing and legal guidance of conduct', Canadian Journal of Law and Jurisprudence, 25 (2012), 359-91 at pp. 373-89. Herein I will confine myself to the brief illustrations below.

50 See, e.g., Raymond Baumhart, An Honest Profit: What Businessmen Say About Ethics in Business (New York: Holt, Rinehart and Winston, 1968), pp. 20-5; Laurie Larwood and William Whittaker, 'Managerial myopia: self-serving biases in organizational planning', Journal of Applied Psychology, 62 (1977), 194-8; Ola Svenson, 'Are we all less risky and more skillful than our fellow drivers?' Acta Psychologica, 47 (1981), 143-8; Jonathon D. Brown, 'Evaluations of self and others: self-enhancement biases in social judgments', Social Cognition, 4 (1986), 353-76; Justin Kruger and David Dunning, 'Unskilled and unaware of it: how difficulties in recognizing one's own incompetence lead to inflated self-assessment', Journal of Personality and Social Psychology, 77 (1999), 1121-34. See also K. Patricia Cross, 'Not can, but will college teaching be improved?' New Directions for Higher Education, (1977), 1-15 at pp. 8-12.
} 
hyperbolic discounting: ${ }^{51}$ namely, a tendency for people to overvalue immediate gratifications and benefits (e.g., gaining a few seconds by not having to wait for the green light) at the expense of remoter or more abstract benefits (e.g., avoiding an inconspicuous but real risk of a road accident).

Or, as another example, an individual experiencing even a moderate financial difficulty may all too easily come to believe that his specific difficulty is such that it outweighs the moral reasons to perform his part in upholding the common good by paying a tax required by the law. Well intentioned as he may be, his judgement is nevertheless prone to be somewhat overly sensitive to his individual circumstances and needs, at the expense of wider considerations of equity and social wellbeing. For, as Albert Venn Dicey once noted, '[a] man's interest gives a bias to his judgement far oftener than it corrupts his heart ${ }^{\prime 52}$-a human propensity well documented in modern empirical studies under the label self-serving bias. ${ }^{53}$

The problems illustrated by these examples are not confined to just a small handful of laws or a few specific situations. They are problems associated with prevalent characteristics of law and the decision-making environment in which its subjects operate, such as the fact that legal rules are typically designed and applied in a prospective manner with the aim of forming social arrangements sustainable through time, whereas decisions made by citizens in the course of day-to-day activity are often instantaneous decisions about how to act here and now; or the fact that in creating and maintaining cooperative schemes for the benefit of society at large, law typically imposes on individuals restrictions and burdens which are at variance with their nearest self-interest and immediate preference. Such tensions are inherent to the operation of law and inevitably present in the decision-making environment of its subjects.

51 See, e.g., George Ainslie, 'Specious reward: a behavioral theory of impulsiveness and impulse control', Psychological Bulletin, 82 (1975), 463-96; Richard J. Herrnstein, 'Rational choice theory: necessary but not sufficient', American Psychologist, 45 (1990), 356-7; Gordon C. Winston and Richard G. Woodbury, 'Myopic discounting: empirical evidence', Handbook of Behavioral Economics, ed. S. Kaish and B. Gilad, vol. 2B (Greenwich, CT: JAI Press, 1991), pp. 325-42; Kris N. Kirby and Richard J. Herrnstein, 'Preference reversals due to myopic discounting of delayed reward', Psychological Science, 6 (1995), 83-9; Kris N. Kirby, 'Bidding on the future: evidence against normative discounting of delayed rewards', Journal of Experimental Psychology: General, 126 (1997), 54-70.

52 Albert V. Dicey, Lectures on the Relation Between Law and Public Opinion in England During the Nineteenth Century, 2nd ed. (London: Macmillan, 1914), p. 15.

53 See, e.g., David M. Messick and Keith P. Sentis, 'Fairness and preference', Journal of Experimental Social Psychology, 15 (1979), 418-34; David M. Messick, 'Social interdependence and decision making', Behavioral Decision Making, ed. G. Wright (New York: Plenum, 1985), pp. 94-100; Leigh Thompson and George Loewenstein, 'Egocentric interpretations of fairness and interpersonal conflict', Organizational Behavior and Human Decision Processes, 51 (1992), 176-97; Linda Babcock and George Loewenstein, 'Explaining bargaining impasse: the role of self-serving biases', Journal of Economic Perspectives, 11 (1997), 109-26; Erica Dawson, et al., 'Motivated reasoning and performance on the Wason selection task', Personality and Social Psychology Bulletin, 28 (2002), 1379-87. See further: Greg Pogarsky and Linda Babcock, 'Damage caps, motivated anchoring, and bargaining impasse', Journal of Legal Studies, 30 (2001), 143-59. 
Against this background, it is easy to appreciate why the attitude I earlier designated lawindifference renders its possessors highly prone to substantive errors. This type of attitude does nothing to predispose its possessors against the foregoing situational biases. It fails to generate in them any form of systematic resistance to those biases against compliance, and leaves them far too exposed and amenable to their influence. Subjects with this attitude, then, are likely to end up defying the law where they ought to follow it. Law-indifference is therefore not an attitude that (in a reasonably just state) individuals should generally aspire to have and society should nurture in its members.

Before turning to what I consider to be the desirable attitude towards law, I should add two clarifications. First, I said above that a law-indifferent attitude is liable to leave its possessors overly exposed to certain biases which are likely to result in moral and practical errors. One element of this argument, which may be worth explicating at this point, is that law-indifferent actors are not likely to effectively detect those biases and correct for them on a case-by-case basis, without changing their general attitude towards law. This is so because in situations where individuals are affected by biases, they tend not to recognise the fact that, or the degree to which, they are thus affected. It is part of the nature of biases that they largely operate at an unconscious or not fully conscious level. They colour our perception of things while leaving us under the impression that we see things as they are. This much is implied by the very notion of bias. But it also finds ample empirical support in recent experimental studies, where the tendency for people to overlook their own biases or underestimate their extent has been borne out and given the name the bias blind spot. ${ }^{54}$

A second clarification worth making is that nothing in what I say here is meant to suggest that cultivating a certain normative attitude towards law is the only measure by which compliance with law can be encouraged. There are, of course, other measures that legal systems can and do employ to this end. Notably, they create prudential reasons not to violate their laws by threatening to punish those who do so. It is crucial to recognise, however, that although legal punishment is probably necessary for the efficacy of a legal system, it is by no means sufficient for it. ${ }^{55}$ For one thing, the economic and practical constraints within which

54 Emily Pronin, et al., 'The bias blind spot: perception of bias in self versus others', Personality and Social Psychology Bulletin, 28 (2002), 369-81; Emily Pronin, et al., 'Objectivity in the eye of the beholder: divergent perceptions of bias in self versus others', Psychological Review, 111 (2004), 781-99; Joyce Ehrlinger, et al., 'Peering into the bias blind spot: people's assessment of bias in themselves and others', Personality and Social Psychology Bulletin, 31 (2005), 680-92; Cynthia McPherson-Frantz, 'I AM being fair: the bias blind spot as a stumbling block to seeing both sides', Basic and Applied Social Psychology, 28 (2006), 157-67. See also James Friedrich, 'On seeing oneself as less self-serving than others', Teaching of Psychology, 23 (1996), 107-9. For example, participants in one experiment who, in assessing themselves on various personality dimensions, exhibited the 'better-than-average effect' - a manifestation of self-enhancement bias-later insisted that their assessments were accurate despite being presented with a description of this bias and invited to acknowledge that they were subject to it (Pronin, et al., 'The bias blind spot', p. 375).

55 See, e.g., Tyler, Why People Obey the Law, pp. 22-3, 65, and references therein. 
enforcement institutions inevitably operate mean that there is only a limited amount of law violation that they can monitor, investigate, prosecute, and punish. A legal system, therefore, cannot depend for its efficacy solely or even mainly on coercive enforcement measures. And even if such a system were possible, the frequency and intensity with which it would have to punish people and use auxiliary enforcement measures, such as surveillance, searches, and arrests, would render it a radically unpalatable method of governance.

If these observations are correct, a legal system requires for its efficacy not only coercive measures of enforcement, but also the prevalence of a certain normative attitude towards law: namely, it is requisite that the bulk of its subjects be law-abiding citizens-that they possess an attitude which may be called a law-abiding disposition. ${ }^{56}$ As I understand it, this attitude has three notable characteristics: (i) as is often the case with attitudes, it has a degree of deep-seatedness and persistence-it is not merely a momentary response to a particular situation or a fleeting state of mind, but rather normally an attitude that the actor has absorbed from a relatively early stage of his upbringing and that tends to endure through time; ${ }^{57}$ (ii) a person with this attitude normally regards the fact that law requires an action as a reason for its performance-law has acquired in her practical deliberation the significance of a reason that applies independently of situational assessments of whether particular acts of compliance would serve the substantive goals or values underlying it; and (iii) she assigns that reason a degree of priority that allows it to ordinarily (but not always, come what may) prevail within its scope of application. In other words, she is generally inclined to follow the law. This does not mean that, when faced with a legal requirement, other reasons cease to have any practical significance for her. An inclination to comply with law, being no more than an inclination, need not be absolutely determinative of how one acts in a given situation; rather, it is likely to remain overridable by sufficiently powerful reasons against compliance which may crop up in a specific situation. But the attitude in question does mean that its possessor complies with law in at least the ordinary run of cases and that she does so in a fairly habitual manner, without having to delve time and again into

\footnotetext{
${ }^{56}$ Being law-abiding and obeying are two different things: the law-abiding may have an inclination to obey the law, which means that they usually do so-but they need not always obey the law. Edmundson has gone further by distinguishing the former (or, what he calls law-abidance) from being disposed to obey the law (William A. Edmundson, 'The virtue of law-abidance', Philosophers' Imprint, 6 (2006), 1-18 at pp. 2-5, 7). I will not make use of this further distinction here. I will use phrases such as 'disposition to comply with law' interchangeably with 'lawabiding disposition'. Other differences between Edmundson's stance and mine involve, firstly, the content of what he calls law-abidance and what I call a law-abiding disposition; and, secondly, the fact that, unlike him, I do not cast my argument in terms of virtue ethics. In this connexion, see Aristotle's virtue-oriented approach to lawabidingness as expressed in Nicomachean Ethics, bk. V, 1129a30-b15, and Politics, bk. III, 1277a25-7, b13-17, bk. V, $1307 \mathrm{~b} 1-5$.

57 I say 'tends' because the attitude under discussion need not be a permanent attitude that can never be abandoned or changed. Rather, its relative fixedness only means that abandoning or changing it may be difficult and normally takes time. It is not done on a case-by-case basis.
} 
extensive deliberation on the reasons underlying the law and actively examine their applicability and weight on a case-by-case basis.

It is easy to see how this practical attitude can serve as an effective counterforce to the earlierdiscussed situational biases against compliance with law. Since people with this attitude treat law as a reason independently of case-by-case assessments of substantive considerations for compliance, the biases implicated in such assessments will have less influence on their decisions under the law. By thus treating law, they let its normative force feed into their decisions without first being mediated and watered down by the situational biases discussed above. Moreover, because such actors are disposed to treat legal requirements as reasons that ordinarily take priority within their ambit, they are less prone to be swayed into lawbreaking by those undue influences that their daily environment of decision-making tends to trigger.

Before bringing the discussion to a close, it will be useful to consider the arguments of another theorist who has given attention to the attitudinal dimension of our problem-Leslie Green. Green has considered and eventually denied what he calls 'a virtue of obedience'.58 Although I have not advocated this notion, but rather the notion of a law-abiding disposition as characterised above, there are some relevant points of contrast between our analyses: first, Green seems to suppose that a habit of obedience could not leave one sufficiently discriminating to be able to defy seriously unjust requirements, because '[n] habit of obedience could be conditional [on one's own view of the merits]'. ${ }^{59}$ This, however, seems to overlook the possibility of an inclination or tendency whose influence on our conduct is overridable, rather than absolutely determinative of how we act in a given situation. That is a key feature of the law-abiding disposition advocated here. While it is true that such a disposition exerts upon us a force which is content-independent, ${ }^{60}$ this does not mean that it also excludes from our horizon other, content-dependent factors, which may compete with it and, when sufficiently powerful, override it. Content-independence of a given factor does not entail the exclusion of other, competing factors. Moreover, law-abiding dispositions may vary in strength-they can be weaker or stronger-and although some individuals might have too strong a disposition to comply with legal directives, there is no reason why this should be the case with most people, at least not within the context of political cultures less than radically authoritarian. There is no reason why the ordinary and common disposition to comply with law may not fall within reasonable bounds in terms of its strength; and even if such a disposition is a tool that inevitably retains a degree of crudeness and imperfection, if my earlier observations are correct it is the best alternative we have.

\footnotetext{
${ }^{58}$ Green, The Authority of the State, pp. 255-67.

59 Ibid., 262.

60 Or, at least, content-independent in some limited sense-see note 22 above and my 'Are legal rules contentindependent reasons?', Problema, 5 (2011), 175-210 at pp. 187-96.
} 
Setting aside the differences between the normative attitudes Green criticises and I advocate, there is another factor which I think his analysis underestimates: that is, the essential role that such an attitude has in counteracting common biases against compliance, as explicated above. He seems to suppose that the absence of such an attitude would not result in an unacceptable quantum of disobedience because reasons of prudence and beneficence that favour compliance-such as the risk of being punished and of stimulating others into unjustified disobedience-would still have their say in people's practical deliberation. ${ }^{61}$ As argued above, however, the prudential reasons which punishment institutions can realistically and palatably generate would not suffice as a countermeasure against common situational biases. ${ }^{62}$ As for reasons of beneficence: common biases of the kind discussed above mean that even if such reasons should get their full weight in the decision about whether to comply or not, in a society whose members are not predisposed to comply with law, too many people in too many cases would not actually accord those reasons their full weight. The disposition I endorse here avoids this problem because it exerts its force independently of our situational assessments and the biases they implicate. ${ }^{63}$

If I am right to make the observations I have made here about the frequent presence of situational biases against compliance in our everyday settings of activity, about the shortcomings of punishment practices, and about the role that our law-abiding disposition can play in counteracting those biases, then our conclusion should be that, in a reasonably just polity, there are good reasons to adopt and cultivate such a disposition. ${ }^{64}$

${ }^{61}$ Green, The Authority of the State, pp. 252-6.

62 See text following note 54 .

63 Green endorses what he calls a virtue of civility or restraint, which 'counsel[s] compliance' in some cases where the injustice of a law 'is found to be both within the bounds of tolerability and not easily avoided' (Green, The Authority of the State, p. 265). These cases do not seem to encompass all the error-prone situations I have discussed above, but even insofar as they do there remains the following question: does Green believe that this type of civility and restraint should be internalised and acquire some degree of embeddedness and fixedness in people? If so, it becomes qualitatively identical (though narrower in scope) to the attitude endorsed here. Without such internalisation, on the other hand, it has no real prospect of success as an effective counterforce to the human tendencies and fallibilities discussed in this section.

${ }^{64}$ I take no stance here on whether these reasons, as far as they apply to the person acquiring this attitude, should be classified as 'state-given' reasons to have this attitude or 'object-given' reasons to try to bring it about that one has it or to cause oneself to have it. The wording I have mostly used in this context-for example, reasons to adopt/cultivate this attitude-is, I think, reconcilable with either alternative. For the debate regarding state/object-given reasons (framed in these or similar terms) see, e.g., Robert Dunn, 'Akratic attitudes and rationality', Australasian Journal of Philosophy, 70 (1992), 24-39; Derek Parfit, 'Reasons and rationality', Exploring Practical Philosophy, ed. D. Egonsson, et al. (Burlington, VT: Ashgate, 2001), pp. 17-39; Berent Enç, How We Act: Causes, Reasons, and Intentions (Oxford: Clarendon Press, 2003), pp. 30-7; Christian Piller, 'Content- related and attitude-related reasons for preferences', Philosophy, 81 (2006), 155-81; James Morauta, 'In defence of state-based reasons to intend', Pacific Philosophical Quarterly, 91 (2010), 208-28; Derek Parfit, On What Matters, vol. 1 (Oxford: Oxford University Press, 2011), pp. 50-1, 420-32; Mark Schroeder, 'The ubiquity of state-given reasons', Ethics, 122 (2012), 457-88. 


\section{CONCLUSION}

I have begun this inquiry with a discussion of normative grounds for the obligation to obey the law, focusing primarily on considerations of necessity and fairness. We have seen that these considerations gain much of their force not through their separate and independent operation, but rather through their symbiotic, mutually supportive relation (as expressed in what I have called the integrated argument). This is so firstly because, unlike a pure necessity argument, the integrated argument holds good beyond the confines of situations in which a disobedient act would actually destabilise the law's effective authority; and secondly because, unlike the traditional fair-play argument, the integrated argument holds good regardless of whether the relevant actor has voluntarily chosen the goods in question. In this way, the integrated argument yields an obligation whose scope is considerably wider than the sum of its parts.

Nevertheless, I have argued that even the integrated argument does not extend to all circumstances of our action under the law. For instance, it does not apply to situations in which even if everyone disobeyed no harm would follow (and no benefit would ensue from their obedience), as in the case of a driver who comes upon a traffic light on a lonely road with no other car or pedestrian in the vicinity. In such circumstances an act of law violation would have no adverse effect whatsoever, even if performed by everyone who found themselves in these circumstances. Thus, an actor who contravenes the law in such a situation does not assume by that very act a liberty or an advantage that, as a rational actor, she would not be willing to extend to others. This means that her act should not be regarded as an unfair act precluded by the integrated argument-which is to say that the argument fails to establish an obligation to obey the law in the general sense that concerns us.

Subsequent discussion, however, has led to a qualification of this position: even if there is nothing wrong with an act of law violation done in situations such as the lonely traffic light case, the attitude from which such an act ensues implicates acute problems. Most notably, it leaves its possessors highly exposed and amenable to the influence of situational biases which typically operate in their decision-making environment and which are liable to lead them to sub-optimific and unjustified law violations. I have contrasted that attitude towards law with another which I termed a law-abiding disposition - an attitude that consists in treating the fact that law requires an action as a reason which applies irrespective of situational assessments of whether a given act of compliance would serve the substantive goals behind the law, and which enjoys some degree of priority within its scope of application. This attitude, I have argued, renders its possessors less prone to be swayed by situational biases against compliance with law. Indeed, its internalisation is essential for law's ability to effectively guide conduct and fulfil its necessary functions in society. I have concluded that, even if there is no 
obligation to obey the law, the subjects of a reasonably just legal system have good reasons to adopt and cultivate a law-abiding disposition.

As a final note, it is appropriate to bring to mind the limits and wider context of this inquiry: I do not purport to have provided here a complete and conclusive answer to the question of the obligation to obey the law and its relation to the value of a law-abiding disposition. I cannot claim to have done that mainly because, as cautioned at the outset, 65 my analysis has assumed arguendo at least one premise that would not be concurred with by all philosophers: ${ }^{66}$ namely, the premise that an action cannot be morally obligatory unless the action itself or its consequences satisfy or serve some moral value. I have proceeded on this premise because it is a premise that underlies much of the contemporary scepticism about the obligation to obey the law, 67 and because my main goal has been to demonstrate that even from that sceptical perspective the value of a law-abiding disposition should be acknowledged. A more definitive conclusion about the obligation to obey the law, however, would necessitate a close examination of the above premise and its ethical foundations. If that premise turns out to be incorrect because, for instance, an action that serves no moral value can nonetheless be morally obligatory if it flows from an attitude (or an internalised maxim) that does, then the observations I have made here may after all translate into an obligation to obey the law. This, however, is a question that lies beyond the limits I have set for the present inquiry.

\footnotetext{
${ }^{65}$ See text between notes 9 and 11 .

${ }^{66}$ See notes 10 and 27.

${ }^{67}$ See citations in note 11.
} 